\title{
Performance and Meat Quality of West African Dwarf (WAD) Sheep Fed with Improved Dried Elephant Grass Supplemented with Legume Straw Under Different Rearing Systems
}

Hakeem - Ishola ( $\nabla$ abdulhakeemadisa5@gmail.com )

Kwara State University https://orcid.org/0000-0002-2368-2644

Ololade Latifat Abdulrahman

Kwara State University

Yusuf Olatunji Ambali

Kwara State University

Felicia Motunrayo Olooto

Kwara State University

Nofiu Babatunde Nafiu

Kwara State University

Ibrahim Folorunsho Ayanda

Kwara State University

\section{Research Article}

Keywords: Indoor Feeding System, Free grazing, Elephant grass and Legume straw

Posted Date: January 25th, 2022

DOI: https://doi.org/10.21203/rs.3.rs-1228594/v1

License: (c) (1) This work is licensed under a Creative Commons Attribution 4.0 International License.

Read Full License 


\section{Abstract}

8 weeks growth and meat quality of WAD sheep study were carried out to compare the digestibility of improved dried elephant grass (EG) (Pennisetum purpureum) supplemented with legume straw (LS) (Lablab purpureus) reared under indoor feeding system (IFS) and free grazing (FG). Twenty-four male west African dwarf (WAD) winner sheep with initial average body weight of $16 \pm 0.5 \mathrm{~kg}$ were assigned to four dietary treatments in a completely randomized design arrangement. Treatments consisted of T1 (sheep on EG and LS free grazing), indoor feeding system IFS; T2 (EG 80\%, LS 20\%), T3 (EG 70\%, LS 30\%) and T4 (EG 60\%, LS 40\%). The results showed that the final body weight of sheep on indoor feeding system T4 differed significantly $(P<0.05)$ from that of sheep on free grazing, T2 and T3. Physicochemical properties were better in sheep meat on IFS (EG 60\%, LS 40\%) compared with other system including FG, control treatment. The sensory perception and fatty acid profiles of sheep meat on IFS were better compared with the sheep meat on FG system. These results showed that rearing of WAD sheep on indoor feeding system were better in terms of growth performance and its meat quality and could serve as an alternative to free grazing especially in region where there are incessant clashes between herders and crop farmers.

\section{Introduction}

In animal production, fattening is a genetic and environmental variable that impacts the animal's performance and carcass features (Wood et al.,2008). As a result of climate change and global warming, there has been a rise in sea level, which has resulted in flooding and the devastation of farm fields, as well as an increase in temperature, which has resulted in deforestation, desertification, and a reduction in grazing land. It is apparent that the obstacles posed by natural disasters would result in pastoralists reducing their grazing areas, which will eventually lead to confrontations between pastoralists and indigenous crop producers. This confrontation has resulted in the loss of lives, property, and livestock. Aside from disputes between pastoralists and crop farmers, many studies have found that wild animals harm livestock raised for grazing pasture productivity (Christiansen et al., 2001; Fleming et al., 2006).

Although many African countries' animal fattening systems rely heavily on the use of grazed pastures, it is clear that grazing production systems are dangerous and time-consuming, with the resultant effect of grazing lands rapidly disappearing across the continent and the livestock production system gradually shifting from grazing to indoor rearing (Alexandre et al., 2009).

The focus of research should be transferred to a fattening system experiment as an alternative to large grazing of grassland by ruminant animals. There is currently little or no data on the effectiveness of indoor grass-based fattening methods for improving performance, carcass production, and meat quality in west African dwarf (WAD) sheep. As a result, the goal of this study was to assess the performance, carcass features, and meat quality of west African dwarf sheep fed on a free-range grazing system and against an indoor grass-based feeding system. 


\section{Materials And Methods}

The feeding trials were carried out at the teaching and research farm, Kwara State University, Malete, Kwara State, Nigeria. While the laboratory analysis was carried out at Central Research, Laboratory and Diagnostic Centre, Tanke Ilorin, Kwara State, Nigeria.

\section{Feeding Trials}

In this study, twenty-four male sheep (WAD) were employed. In three replicates, two feeding trial systems were evaluated using a completely randomized layout. T1 (animals grazed in a fenced area on an irrigated mixture of elephant grass and legume straw with a stocking rate of $100 \mathrm{~kg} / \mathrm{ha} / \mathrm{month}), T 2, T 3$, and T4 (animals kept inside in a pen and fed $5 \%$ of their body weight on a daily basis with the same diets but in varied amounts) The fattening stage lasted 8 weeks, and careful management methods, including vaccination and proper medicine administration, were strictly followed.

\section{Experimental Diets}

$\mathrm{T} 1$ = grazing ad libtum on combination of elephant grass and legume straw (lablab) (control)

T2 = indoor feeding with elephant grass (80\%), legume straw lablab (20\%)

T3 = indoor feeding with elephant grass (70\%), legume straw lablab (30\%)

T4 = indoor feeding with elephant grass (60\%), legume straw lablab (40\%)

\section{Data Collections}

\section{Feed intake and Weight Gain}

During the 8-week feeding trial, sheep were weighed on the first day and weekly thereafter. The difference between weekly weight readings was used to calculate body weight gain. Throughout the feeding trial, daily feed consumption was documented.

\section{Digestibility determination}

The digestibility test took place two weeks before to the slaughter. For 7 days, one animal from each replicate was placed in the metabolic crates. With the exception of T1, drinking water was available at all times, and the feed was delivered twice daily. The leftover feed was collected, and the amount of feed consumed was recorded. Samples of feed were taken and dried in the oven. For further analysis, the dried materials were ground and stored in a container. Fecal samples were obtained from each replicate's animals, dried, powdered, and stored in a plastic container for chemical analysis using the micro-Kjeldahl technique (AOAC, 1990).

\section{Carcass Traits}


Prior to slaughter, the animals were fasted for the night. Each replicate had an animal slaughtered, deskinned, and eviscerated. Weighing and recording primal cut portions was done. Meat quality was determined using the longissimus lumborum portions from each animal.

\section{Haematology and Serum biochemistry analysis}

Blood samples $(5 \mathrm{ml})$ were drawn from each sheep's jugular vein using a $10 \mathrm{ml}$ syringe and needles and placed in a bottle containing ethylene diamine tetra acetic acid (EDTA) and centrifuged for 10 minutes at $3000 \mathrm{rpm}, 4^{\circ} \mathrm{C}$. Haematological parameters such as Red Blood Cells (RBC), White Blood Cells (WBC), Packed Cell Volume (PCV), and Haemoglobin $(\mathrm{Hb})$ concentration were determined using the plasma fraction. The blood samples for biochemical analysis were collected into a serum tube, kept at $0-4^{\circ} \mathrm{C}$ on crushed ice for 2 hours, and then transported to the laboratory as described by Jain (1993) and Dachie and Lewis (2001).

\section{Sensory evaluation}

As outlined by Meilgaard et al. (2006), a consumer-type sensory examination was conducted. Each sheep replicate had $20 \mathrm{~g}$ of longissimus lumborum cut free of fat, labeled, and cooked in a water bath at $80^{\circ} \mathrm{C}$ for 10 minutes. Twenty (20) assessors participated in a consumer-type sensory evaluation. Assessors were taught on the sensory protocol and given criteria to score using a 9-point hedonic scale (appearance, taste, texture, scent, and overall acceptability) (Meilgaard et al., 2006). A score of nine denoted overwhelming liking, while a score of one indicated extreme dislike.

\section{Colour coordinates}

The meat samples' colour coordinates were determined using the method provided by Sabow et al (2015). The meat pieces were sliced into $1 \mathrm{~cm} \times 1 \mathrm{~cm} \times 2 \mathrm{~cm}$ sections and placed on a Colour Flex spectrophotometer's colour flex cup. Lightness $\left(L^{*}\right)$, redness $\left(a^{*}\right)$, and yellowness $\left(b^{\star}\right)$ of the meat samples were all measured.

\section{Water holding capacity, pH and Drip loss}

Using a portable $\mathrm{pH}$ meter, the $\mathrm{pH}$ of muscles was assessed using the AMSA (2012) approach (Mettler Toledo, AG 8603 , Switzerland). To avoid glycolysis, $0.5 \mathrm{~g}$ of the meat samples were homogenized in a beaker with $10 \mathrm{ml}$ cold water and $5 \mathrm{M}$ sodium iodoacetate. At room temperature, the $\mathrm{pH}$ of the homogenates was determined. The meat samples' drip loss was measured as specified by (Sabow et al., 2015). Fresh meat samples from the longissimus lumborum muscle were weighed as initial weight after slaughter (W1). The weighed beef samples were sealed in polyethylene bags, labeled, and kept at $4^{\circ} \mathrm{C}$ in the refrigerator. The meat samples were removed out of the bags, gently dried, blotted, and weighed as W2 at the end of day 3 postmortem. Drip loss was estimated and expressed as a percentage of the difference between the sample's initial and final weight after storage, divided by the sample's starting weight, as shown below: 


\section{Drip loss $(\%)=W 1-\frac{W 2}{W 1} \times 100$ \\ Fatty acid profiles}

The approach first published by Folch et al. (1957), refined by Rajion et al. (1985), and adopted by Adeyemi et al. (2015) was used to extract meat lipid samples in a chloroform: methanol (2:1, v/v) mixture. According to AOAC (2007) methods, the fatty acids were transmethylated into fatty acid methyl esters (FAME) using $0.66 \mathrm{M}$ potassium hydroxide $(\mathrm{KOH})$ in methanol and 14 percent methanolic boron trifluoride (BF3) and separated in a gas chromatograph (Agilent 7890A).

\section{Statistical Analysis}

The PROC MIXED technique of SAS (2014) was used to do an analysis of variance (ANOVA) on the data collected. At a $5 \%$ significant level, the means were separated.

\section{Results}

The results of growth performance of the experimental animals on different dietary production systems were shown on Table 1. There were no significant differences $(p>0.05)$ on the initial body weight (IBW) of the experimental animals. However, the final body weight (FBW), total weight gain (TWG) and average weight gain (AWG) of experimental sheep on dietary production system indoor feeding with elephant grass $0.6 \%$, legume straw $0.04 \%$ (EG $0.6 \%$, LS $0.4 \%)$ were significantly higher $(\mathrm{p}<0.05)$ compared with sheep on EG $0.7 \%$, LS $0.3 \%$ dietary production system, which was in turn higher $(p<0.05)$ than those sheep on dietary EG $0.8 \%$, LS $0.2 \%$. The sheep on free grazing (FG), the control experiment, had the lowest FBW, TWG and AWG and were significantly lower $(p>0.05)$ than all sheep on other dietary production system. The dry matter intake (MDI) of sheep on FG production system were significantly higher $(p<0.05)$ than sheep on other dietary production system. However, there were similarities $(p>0.05)$ in ADFI of sheep on dietary production system of EG $0.8 \%$, LS $0.2 \%$ and EG $0.7 \%$, LS $0.3 \%$ which in turn were significantly higher $(p<0.05)$ than sheep on dietary production system EG $0.6 \%$, LS $0.4 \%$. Sheep on EG $0.6 \%$, LS $0.4 \%$ were significantly lower $(p>0.05)$ in MDI compared with other treatments. The feed conversion ratio (FCR) of sheep on FG dietary production system were significantly higher $(p<0.05)$ compared with sheep on EG $0.8 \%$, LS $0.2 \%$, which in turn was significantly higher than those on EG $0.7 \%, \mathrm{LS} 0.3 \%$. Sheep on dietary production system EG $0.6 \%$ LS $0.4 \%$ had the lowest FCR value and were significantly lower $(p>0.05)$ than sheep on other dietary production system, including the control treatment.

The results of nutrient digestibility of the sheep on different dietary production systems were indicated in Table 2. There were no significant differences ( $p>0.05$ ) on the crude protein (CP) and crude fibre (CF) of the sheep on different dietary production systems. However, the sheep on free grazing (FG)s had a higher $(p<0.05)$ ether extract $(E E)$ value compared with other dietary treatments. There were similarities $(p>0.05)$ in the CL of sheep on EG 0.8\% LS $0.2 \%$, EG $0.7 \%$ LS $0.3 \%$ and EG $0.6 \%$ LS $0.4 \%$. The experimental sheep on dietary production system EG $0.6 \%$ LS $0.4 \%$ and EG $0.7 \%$ LS $0.3 \%$ were similar but significantly higher 
$(\mathrm{p}<0.05)$ in ash value of the nutrient digestibility compared with sheep on EG $0.8 \%$ LS $0.2 \%$ treatment, which in turn was significantly higher $(p<0.05)$ than ash value of sheep on free grazing $(F G)$, the control treatment. Sheep on FG production system had the lowest ( $p>0.05)$ ash value. The sheep on dietary production system EG $0.6 \%$ LS $0.4 \%$ and EG $0.7 \%$ LS $0.3 \%$ were similar but significantly higher $(p<0.05)$ in organic matter and neutral detergent fibre (NDF) compared with sheep on EG $0.8 \%$ LS $0.2 \%$ and FG treatments, which were in turn similar in organic matter and NDF.

Table 1

Growth Performance of Sheep Primal Cuts Fed under Different Treatments

\begin{tabular}{|c|c|c|c|c|c|c|}
\hline \multicolumn{3}{|l|}{ Parameters } & \multicolumn{4}{|l|}{ Treatments } \\
\hline & FG & $\begin{array}{l}\mathrm{EG}(0.8 \%), \mathrm{LS} \\
(0.2 \%)\end{array}$ & $\begin{array}{l}\mathrm{EG}(0.7 \%), \mathrm{LS} \\
(0.3 \%)\end{array}$ & $\begin{array}{l}\text { EG }(0.6 \%), \text { LS } \\
(0.4 \%)\end{array}$ & SEM & $P$ value \\
\hline IBW (kg) & 16.20 & 16.10 & 16.3 & 16.5 & 0.13 & $>0.3$ \\
\hline FBW (kg) & $19.22^{d}$ & $19.58^{c}$ & $19.95^{b}$ & $20.32^{a}$ & 0.02 & $<0.0001$ \\
\hline TWG (kg) & $3.02^{d}$ & $3.48^{c}$ & $3.65^{b}$ & $3.82^{\mathrm{a}}$ & 0.02 & $<0.0001$ \\
\hline AWWG (g) & $378^{d}$ & $435.4^{c}$ & $456.4^{b}$ & $477.4^{a}$ & 0.51 & $<0.0001$ \\
\hline DMI (g) & $825^{a}$ & $695^{\mathrm{b}}$ & $701^{b}$ & $685^{c}$ & 1.58 & $<0.0001$ \\
\hline FCR & $15.28^{a}$ & $11.17^{b}$ & $10.75^{c}$ & $10.04^{d}$ & 0.02 & $<0.0001$ \\
\hline \multicolumn{7}{|c|}{$\begin{array}{l}\text { The means in the rows represented by the same alphabets are not significantly different }(p>0.05) \text {. } \\
\text { IBW- Initial body weight, FBW- Final body weight, TWG- Total weight gain, AWWG- Average weekly } \\
\text { weight gain, DMI- Dry matter intake, FCR- Feed conversion ratio, FG- Free grazing, EG- Elephant grass, } \\
\text { LS- Legume straw }\end{array}$} \\
\hline
\end{tabular}


Table 2

Nutrient Digestibility of Sheep Fed under Different Treatments

\begin{tabular}{|c|c|c|c|c|c|c|}
\hline Nutrients & Treatmen & & & & & \\
\hline$(g / d)$ & FG & $\begin{array}{l}\mathrm{EG}(0.8 \%), \mathrm{LS} \\
(0.2 \%)\end{array}$ & $\begin{array}{l}\text { EG(0.7\%),LS } \\
(0.3 \%)\end{array}$ & $\begin{array}{l}\mathrm{EG}(0.6 \%), \mathrm{LS} \\
(0.4 \%)\end{array}$ & SEM & $P$ value \\
\hline $\begin{array}{l}\text { Crude } \\
\text { Protein }\end{array}$ & 6.04 & 6.11 & 6.27 & 6.93 & 0.16 & $>0.05$ \\
\hline $\begin{array}{l}\text { Ether } \\
\text { Extracts }\end{array}$ & $8.70^{a}$ & $5.38^{b}$ & $5.01^{b}$ & $4.76^{b}$ & 0.17 & $>0.0002$ \\
\hline Crude fibre & 1451.52 & 1420.75 & 1429.83 & 1438.34 & 6.49 & $>0.105$ \\
\hline Ash & $9.49 c$ & $13.13^{b}$ & $13.71^{a}$ & $14.04^{\mathrm{a}}$ & 0.09 & $<0.0001$ \\
\hline $\begin{array}{l}\text { Organic } \\
\text { Matter }\end{array}$ & $3.61^{b}$ & $4.31^{b}$ & $5.16^{\mathrm{a}}$ & $5.72^{\mathrm{a}}$ & 0.14 & $>0.0015$ \\
\hline NDF & $66.73^{b}$ & $66.78^{b}$ & $69.18^{a}$ & $69.80^{a}$ & 0.34 & $>0.0031$ \\
\hline
\end{tabular}

The results of carcass characteristics of the sheep on different dietary production systems were shown in Table3. The slaughter weight (SW), cut parts; head, neck, rib, back, shanks and flank weight of the sheep on dietary production systems EG $0.8 \%$ LS $0.2 \%$, EG $0.7 \%$ LS $0.3 \%$ and EG $0.6 \%$ LS $0.4 \%$ were similar but significantly higher $(p<0.05)$ than those sheep on control treatment FG. The dressing percentage (D\%) of sheep on dietary production system EG $0.8 \%$ LS $0.2 \%$ were significantly higher $(p<0.05)$ than those sheep on EG $0.7 \%$ LS $0.3 \%$, which in turn was significantly higher $(p<0.05)$ than those sheep on EG $0.7 \%$ LS $0.3 \%$. Sheep on EG $0.6 \%$ LS $0.4 \%$ had a higher $(\mathrm{p}<0.05) \mathrm{D} \%$ than those sheep on FG, the control treatment. The intestinal weight (ITW) of sheep on EG $0.7 \%$ LS $0.3 \%$ and EG $0.6 \%$ LS $0.4 \%$ were similar but significantly higher $(p<0.05)$ than those sheep on EG $0.8 \%$ LS $0.2 \%$ treatment which in turn was higher $(p<0.05)$ than those sheep on FG control treatment. However, sheep on FG dietary production system was significantly lower $(p>0.05)$ in ITW compared with other treatments. The liver and heart weight of those sheep on EG $0.6 \%$ LS $0.4 \%$ were significantly higher $(p<0.05)$ compared with those sheep on other treatments. However, there were similarities in the liver and heart weight of those sheep on EG $0.8 \% \mathrm{LS}$ $0.2 \%$ and EG $0.7 \%$ LS $0.3 \%$ treatment but were also significantly higher $(\mathrm{p}<0.05)$ than those sheep on control treatment. Whereas, sheep on FG, the control treatment were significantly lower $(p>0.05)$ in liver and heart weight compared with those sheep on other treatments. The abdominal fat (ABF) of sheep on EG $0.8 \%$ LS $0.2 \%$ were significantly higher $(p<0.05)$ than those sheep on both EG $0.7 \%$ LS $0.3 \%$ and EG $0.6 \%$ LS $0.4 \%$. Although, those sheep on EG $0.7 \%$ LS $0.3 \%$ and EG $0.6 \%$ LS $0.4 \%$ showed some similarities in their ABF values but they were significantly higher $(p<0.05)$ in their $A B F$ value compared with those sheep on control treatment which had a significantly lower ABF value compared with sheep on other 
treatments. There were no significant differences in the hot carcass weight, legs, lungs and kidney parts of the sheep on different dietary production systems.

Table 3

Carcass and Non- Carcass Compositions of Sheep Primal Cuts Fed under Different Treatments

Parameters Treatments

\begin{tabular}{|c|c|c|c|c|c|c|}
\hline & FG & $\begin{array}{l}\mathrm{EG}(0.8 \%), \mathrm{LS} \\
(0.2 \%)\end{array}$ & $\begin{array}{l}\mathrm{EG}(0.7 \%), \mathrm{LS} \\
(0.3 \%)\end{array}$ & $\begin{array}{l}\mathrm{EG}(0.6 \%), \mathrm{LS} \\
(0.4 \%)\end{array}$ & SEM & P Value \\
\hline SW (kg) & $17.10^{\mathrm{b}}$ & $17.90^{\mathrm{a}}$ & $17.62^{\mathrm{a}}$ & $17.64^{\mathrm{a}}$ & 0.07 & $>0.006$ \\
\hline HCW (kg) & 9.40 & 9.80 & 9.90 & 10.02 & 0.12 & $>0.07$ \\
\hline Dressing\% & $48.91^{d}$ & $50.05^{a}$ & $49.62^{b}$ & $49.31^{c}$ & 0.01 & $<0.0001$ \\
\hline Head (g) & $1000.00^{b}$ & $1300.00^{a}$ & $1350.00^{a}$ & $1380.00^{a}$ & 29.15 & $>0.002$ \\
\hline Legs (g) & 500.00 & 600.00 & 600.00 & 602.00 & 27.40 & $>0.14$ \\
\hline Neck (g) & $600.00^{b}$ & $700.00^{\text {ba }}$ & $750.00^{a}$ & $780.00^{a}$ & 18.03 & $>0.007$ \\
\hline $\operatorname{Rib}(g)$ & $800.00^{b}$ & $1300.00^{\mathrm{a}}$ & $1300.00^{\mathrm{a}}$ & $1320.00^{a}$ & 15.81 & $<0.0001$ \\
\hline Back (g) & $500.00^{b}$ & $750.00^{a}$ & $800.00^{a}$ & $800.00^{a}$ & 15.81 & $>0.001$ \\
\hline Shanks (g) & $2700.00^{b}$ & $3500.00^{a}$ & $3520.00^{a}$ & $3550.00^{a}$ & 36.08 & $>0.001$ \\
\hline Flank (g) & $1100.00^{b}$ & $1500.00^{a}$ & $1500.00^{a}$ & $1550.00^{a}$ & 37.08 & $>0.003$ \\
\hline ITW (g) & $700.00^{c}$ & $800.00^{b}$ & $900.00^{\mathrm{a}}$ & $950.00^{a}$ & 13.23 & $>0.0001$ \\
\hline Liver (g) & $300.00^{b}$ & $400.00^{\mathrm{ba}}$ & $395.00^{\mathrm{ba}}$ & $405.00^{a}$ & 17.50 & $>0.03$ \\
\hline Heart (g) & $120.00^{b}$ & $200.00^{\text {ba }}$ & $200.00^{\text {ba }}$ & $220.00^{a}$ & 15.81 & $>0.04$ \\
\hline Lungs (g) & 300.00 & 300.00 & 320.00 & 320.00 & 21.21 & $>0.8$ \\
\hline Kidney (g) & 100.00 & 100.00 & 105.00 & 100.00 & 12.34 & $>0.98$ \\
\hline $\mathrm{ABF}(\mathrm{g})$ & $18.48^{\mathrm{C}}$ & $30.58^{a}$ & $30.00^{\mathrm{b}}$ & $29.80^{b}$ & 0.05 & $<0.0001$ \\
\hline
\end{tabular}

Haematological parameters result of sheep on different dietary production systems are shown in Table 4 . The white blood cells WBC of sheep on EG $0.8 \%$ LS $0.2 \%$ were significantly higher $(p<0.05)$ than those 
sheep on EG $0.7 \%$ LS $0.3 \%$ which in turn were higher than those sheep on EG $0.6 \%$ LS $0.4 \%$. However, the WBC of those sheep on control diet FG were significantly lower ( $p>0.05)$ compared with those sheep on other treatments. Sheep on EG $0.6 \%$ LS $0.4 \%$ were significantly higher $(p<0.05)$ in haemoglobin (HGB) value than other treatments but have a similar HGB values with sheep on EG $0.7 \% \mathrm{LS} 0.3 \%$. Similarly, sheep on EG $0.7 \%$ LS $0.3 \%$ and EG $0.8 \%$ LS $0.2 \%$ were similar in HGB values but were also significantly higher $(p<0.05)$ in HGB value than those sheep on $F G$, the control treatment. There were similarities in the packed cell volume (PCV) values of sheep on EG $0.8 \%$ LS $0.2 \%$, EG $0.7 \%$ LS $0.3 \%$ and EG $0.6 \%$ LS $0.4 \%$ but were however significantly higher $(\mathrm{p}<0.05)$ in PCV value than those sheep on $\mathrm{FG}$, the control treatment. Sheep on EG $0.8 \%$ LS $0.2 \%$ were significantly higher $(p<0.05)$ in lymphocytes (LYM) value than other treatments but have a similar LYM values with sheep on EG $0.7 \%$ LS $0.3 \%$. Similarly, sheep on EG $0.7 \%$ LS $0.3 \%$ and EG $0.6 \%$ LS $0.4 \%$ were similar in LYM values but were also significantly higher $(p<0.05)$ in LYM value than those sheep on FG, the control treatment. The Mean corpuscular volume (MCV) and granulocyte (GRAN) values of those sheep on FG, the control treatment was significantly higher $(p<0.05)$ than those sheep on EG $0.8 \%$ LS $0.2 \%$, EG $0.7 \%$ LS $0.3 \%$ and EG $0.6 \%$ LS $0.4 \%$ treatments which in turn had a similar MCV and GRAN value. There were no significant differences in the red blood cells of sheep on different dietary production system.

Table 4

Haematological Parameters of Sheep Fed under Different Treatments

\section{Parameters \\ Treatments}

\begin{tabular}{|c|c|c|c|c|c|c|}
\hline & FG & $\begin{array}{l}E G(0.8 \%), L S \\
(0.2 \%)\end{array}$ & $\begin{array}{l}E G(0.7 \%), L S \\
(0.3 \%)\end{array}$ & $\begin{array}{l}E G(0.6 \%), L S \\
(0.4 \%)\end{array}$ & SEM & $\begin{array}{l}P \\
\text { value }\end{array}$ \\
\hline $\begin{array}{l}\text { WBC }(x \\
\left.10^{9} / I\right)\end{array}$ & $5.10^{d}$ & $6.80^{\mathrm{a}}$ & $6.20^{\mathrm{b}}$ & $5.50^{\mathrm{C}}$ & 0.11 & $<.0001$ \\
\hline $\begin{array}{l}\mathrm{RBC}(\mathrm{x} \\
\left.10^{12} / \mathrm{I}\right)\end{array}$ & 2.40 & 2.42 & 2.80 & 2.80 & 0.09 & $>.06$ \\
\hline $\mathrm{HGB}(\mathrm{g} / \mathrm{l})$ & $77.50^{c}$ & $89.60^{b}$ & $90.60^{a b}$ & $91.80^{a}$ & 0.18 & $>.0006$ \\
\hline PCV (\%) & $21.19^{b}$ & $29.50^{\mathrm{a}}$ & $29.30^{a}$ & $29.10^{a}$ & 5.10 & $<.0001$ \\
\hline LYM (\%) & $74.60^{c}$ & $95.50^{\mathrm{a}}$ & $94.50^{\mathrm{ab}}$ & $92.50^{\mathrm{b}}$ & 0.12 & $<.0001$ \\
\hline MCV (fl) & $23.50^{\mathrm{a}}$ & $20.70^{b}$ & $21.00^{\mathrm{b}}$ & $21.00^{b}$ & 0.23 & $>.0029$ \\
\hline GRAN & $21.90^{a}$ & $3.80^{b}$ & $3.40^{\mathrm{b}}$ & $3.00^{b}$ & 3.20 & $<.0001$ \\
\hline \multicolumn{7}{|c|}{$\begin{array}{l}\text { The means in the rows represented by the same alphabets are not significantly different }(p>0.05) \text {. FG- } \\
\text { Free grazing, EG-Elephant grass, LS- Legume straw, }\end{array}$} \\
\hline \multicolumn{7}{|c|}{$\begin{array}{l}\text { WBC- white blood cell. RBC- red blood cell, HGB- haemoglobin, PCV- packed cell volume, LYM- } \\
\text { lymphocyte, MCV- Mean corpuscular volume, GRAN- granulocyte }\end{array}$} \\
\hline
\end{tabular}


The physicochemical properties result of the sheep on different dietary production systems is shown in Table 5. Sheep on EG $0.6 \%$ LS $0.4 \%$ was significantly higher $(p<0.05)$ in the $\mathrm{pH}$ value compared with those sheep on FG, the control treatment. However, there were similarities in the $\mathrm{pH}$ value of sheep on EG $0.6 \%$ LS $0.4 \%$, EG $0.7 \%$ LS $0.3 \%$ and EG $0.8 \%$ LS $0.2 \%$. Also, sheep on EG $0.7 \%$ LS $0.3 \%$ and EG $0.8 \%$ LS $0.2 \%$ treatment had some similarities in the $\mathrm{pH}$ value compared with those sheep on $\mathrm{FG}$, the control treatment. The water holding capacity (WHC) of sheep on EG $0.8 \%$ LS $0.2 \%$ was similar with that of sheep on EG $0.7 \%$ LS $0.3 \%$ but were significantly higher $(p<0.05)$ in WHC value compared with those sheep on EG $0.6 \%$ LS $0.4 \%$ which in turn had a significant higher $(p<0.05)$ WHC value than those sheep on FG, the control treatment. Sheep on FG treatment has significant higher $(p<0.05)$ drip loss value compared with sheep on EG 0.8\% LS 0.2\%, EG 0.7\% LS 0.3\% and EG 0.6\% LS $0.4 \%$ which in turn have similar drip loss values. The lightness $L^{*}$ of the sheep meat on FG treatment has some similarities with the sheep meat on EG $0.8 \%$ LS $0.2 \%$ but was significantly higher $(p<0.05)$ in $L^{*}$ value of those sheep on EG $0.7 \%$ LS $0.3 \%$ treatment. There was similarity in the $L^{*}$ value of sheep meat on EG $0.7 \% \mathrm{LS} 0.3 \%$ and EG $0.8 \%$ LS $0.2 \%$ but were however significantly higher $(p<0.05)$ in the $L^{*}$ value than those sheep meat on EG $0.6 \%$ LS $0.4 \%$ treatment. The redness a* of the sheep meat on FG treatment has some similarities with the sheep meat on EG $0.8 \%$ LS $0.2 \%$ and EG $0.6 \%$ LS $0.4 \%$. There were similarities in the a* values of sheep meat on EG $0.8 \%$ LS $0.2 \%$ and EG $0.6 \%$ LS $0.4 \%$ which in turn were significantly higher $(p<0.05)$ in $a *$ value of sheep meat on EG $0.7 \%$ LS $0.3 \%$. The yellowness $b$ * value of the sheep meat on EG $0.8 \%$ LS $0.2 \%$ treatment has some similarities with the sheep meat on EG $0.7 \% \mathrm{LS} 0.3 \%$ and $\mathrm{FG}$, the control treatment, but significantly higher $(p<0.05)$ in $b^{*}$ value than those sheep meat on EG $0.6 \%$ LS $0.4 \%$ treatment. There were similarities in the $b^{*}$ values of sheep meat on EG $0.7 \% \mathrm{LS} 0.3 \%$ and FG, the control treatment, which in turn were significantly higher $(p<0.05)$ in $b *$ value of sheep meat on EG $0.6 \%$ LS $0.4 \%$. The force peak value of sheep meat on $\mathrm{FG}$, the control treatment was significantly higher $(p<0.05)$ than those sheep meat on EG $0.8 \%$ LS $0.2 \%$ and EG $0.7 \%$ LS $0.3 \%$. There is a similarity in the force peak value of sheep meat on EG $0.8 \%$ LS $0.2 \%$ and EG $0.7 \%$ LS $0.3 \%$, which in turn were significantly higher $(p<0.05)$ in force peak value of sheep meat on EG $0.6 \%$ LS $0.4 \%$ treatment. The force yield value of sheep meat on FG, the control treatment was significantly higher $(p<0.05)$ than those sheep meat on EG $0.8 \%$ LS $0.2 \%$, EG $0.7 \%$ LS $0.3 \%$ and EG $0.6 \%$ LS $0.4 \%$, which in turn showed similarities in their force yield values. There were no significant differences in the cooking yield, stress peak and stress yield of sheep meat on different dietary production systems. 
Table 5

Physicochemical Parameters of Sheep Meat Fed under Different Treatments

\begin{tabular}{|c|c|c|c|c|c|c|}
\hline \multirow[t]{2}{*}{ Parameters } & \multicolumn{6}{|c|}{ Treatments } \\
\hline & FG & $\begin{array}{l}\mathrm{EG}(0.8 \%), \mathrm{LS} \\
(0.2 \%)\end{array}$ & $\begin{array}{l}\text { EG(0.7\%),LS } \\
(0.3 \%)\end{array}$ & $\begin{array}{l}\mathrm{EG}(0.6 \%), \mathrm{LS} \\
(0.4 \%)\end{array}$ & SEM & $P$ value \\
\hline $\mathrm{Ph}$ & $5.45^{\mathrm{b}}$ & $6.00^{\mathrm{ab}}$ & $6.40^{\mathrm{ab}}$ & $6.80^{\mathrm{a}}$ & 0.19 & $>0.027$ \\
\hline WHC & $17.33^{c}$ & $20.71^{a}$ & $20.41^{a b}$ & $19.30^{\mathrm{b}}$ & 0.21 & $>0.001$ \\
\hline Drip loss & $7.36^{\mathrm{a}}$ & $4.83^{b}$ & $4.61^{b}$ & $4.25^{\mathrm{b}}$ & 0.12 & $>0.0002$ \\
\hline Cooking loss & 34.37 & 35.88 & 35.17 & 34.36 & 0.27 & $>0.042$ \\
\hline \multicolumn{7}{|l|}{$\begin{array}{l}\text { Colour } \\
\text { coordinates }\end{array}$} \\
\hline Lightness L* & $21.15^{\mathrm{a}}$ & $20.71^{\mathrm{ab}}$ & $20.41^{b}$ & $19.30^{c}$ & 0.10 & $>0.0009$ \\
\hline Redness a* & $1.07^{a}$ & $0.69^{a b}$ & $0.30^{\mathrm{b}}$ & $0.84^{\mathrm{ab}}$ & 0.13 & $>0.001$ \\
\hline Yellowness b* & $15.37^{\mathrm{ab}}$ & $15.97^{a}$ & $15.32^{\mathrm{ab}}$ & $15.15^{b}$ & 0.12 & $>0.029$ \\
\hline \multicolumn{7}{|l|}{ Shear Force } \\
\hline Force peak & $24.60^{a}$ & $17.80^{b}$ & $17.20^{b}$ & $16.0^{c}$ & 0.15 & $<0.0001$ \\
\hline Force yield & $6.20^{\mathrm{a}}$ & $5.10^{\mathrm{b}}$ & $4.80^{\mathrm{b}}$ & $4.80^{\mathrm{b}}$ & 0.16 & $>0.009$ \\
\hline Stress peak & 1.02 & 1.00 & 0.98 & 0.80 & 0.14 & $>0.69$ \\
\hline Stress yield & 0.06 & 0.02 & 0.02 & 0.02 & 0.01 & $>0.22$ \\
\hline \multicolumn{7}{|c|}{$\begin{array}{l}\text { The means in the rows represented by the same alphabets are not significantly different }(p>0.05) \text {. } \\
\text { WHC- water holding capacity, SOD- superoxide dismutase, GP } x^{-} \text {glutathione peroxidase, FG- Free } \\
\text { grazing, EG- Elephant grass, LS- Legume straw }\end{array}$} \\
\hline
\end{tabular}

Sensory perceptions of sheep meat on different dietary production systems are shown in Table 6 . The appearance perception of the sheep meat on dietary EG $0.8 \% \mathrm{LS} 0.2 \%$ were somewhat similar to sheep meat on EG $0.6 \%$ LS $0.4 \%$ but significantly higher $(p<0.05)$ than those sheep on EG $0.7 \%$ LS $0.3 \%$, which in turn was also similar to sheep meat on EG $0.6 \%$ LS $0.4 \%$ but significantly higher $(p<0.05)$ compared with sheep meat on FG, the control treatment. The taste, texture and aroma perceptions of the sheep meat on EG $0.8 \%$ LS $0.2 \%$, EG $0.7 \%$ LS $0.3 \%$ and EG $0.6 \%$ LS $0.4 \%$ treatments were similar but were significantly higher $(\mathrm{p}<0.05)$ than those sheep meat on $\mathrm{FG}$, the control treatment. There were similarities in the overall acceptability of the sheep meat on EG $0.8 \%$ LS $0.2 \%$ and EG $0.6 \%$ LS $0.4 \%$ but were 
however, significantly higher $(\mathrm{p}<0.05)$ than those sheep meat on EG $0.7 \%$ LS $0.3 \%$ which in turn were significantly higher than those sheep meat on FG, the control treatment.

Table 6

Sensory Evaluation of Sheep Meat Fed under Different Treatments

\begin{tabular}{|lllllll|}
\hline Parameters & \multicolumn{2}{ll}{ Treatments } & & & \\
\hline & FG & $\begin{array}{l}\text { EG(0.8\%),LS } \\
(\mathbf{0 . 2 \%})\end{array}$ & $\begin{array}{l}\text { EG(0.7\%),LS } \\
(\mathbf{0 . 3 \%})\end{array}$ & $\begin{array}{l}\text { EG(0.6\%),LS } \\
(\mathbf{0 . 4 \% )}\end{array}$ & SEM & P value \\
\hline Appearance & $7.80^{\mathrm{c}}$ & $8.90^{\mathrm{a}}$ & $8.30^{\mathrm{b}}$ & $8.60^{\mathrm{ab}}$ & 0.14 & $<0.0001$ \\
\hline Taste & $7.40^{\mathrm{b}}$ & $8.10^{\mathrm{a}}$ & $8.20^{\mathrm{a}}$ & $8.70^{\mathrm{a}}$ & 0.20 & $>0.0009$ \\
\hline Texture & $7.60^{\mathrm{b}}$ & $8.90^{\mathrm{a}}$ & $8.30^{\mathrm{a}}$ & $8.80^{\mathrm{a}}$ & 0.20 & $<0.0001$ \\
\hline Aroma & $7.20^{\mathrm{b}}$ & $8.80^{\mathrm{a}}$ & $8.40^{\mathrm{a}}$ & $8.90^{\mathrm{a}}$ & 0.17 & $<0.0001$ \\
\hline $\begin{array}{l}\text { Overall } \\
\text { acceptability }\end{array}$ & $7.40^{\mathrm{c}}$ & $9.00^{\mathrm{a}}$ & $8.00^{\mathrm{b}}$ & $8.80^{\mathrm{a}}$ & 0.12 & $<0.0001$ \\
\hline $\begin{array}{l}\text { The means in the rows represented by the same alphabets are not significantly different (p>0.05). FG- } \\
\text { Free grazing, EG- Elephant grass, LS- Legume straw }\end{array}$ & & & \\
\hline
\end{tabular}

The fatty acid profiles of sheep meat on different dietary treatments are shown in Table 7. The palmitic (C16:0), palmitoleic (C16:1区9c), myristic (C14:0), vaccenic $\left(\mathrm{C}_{18} \mathrm{H}_{34} \mathrm{O}_{2}\right)$ and caproic (C10:0) acid values of sheep meat on dietary FG, the control treatment was significantly higher $(\mathrm{p}<0.05)$ compared with those sheep meat on EG $0.8 \%$ LS $0.2 \%$, EG $0.7 \%$ LS $0.3 \%$ and EG $0.6 \%$ LS $0.4 \%$ treatments. However, there were similarities in the $\mathrm{C} 16: 0, \mathrm{C} 16: 1 \otimes 9 \mathrm{c}, \mathrm{C} 14: 0, \mathrm{C}_{18} \mathrm{H}_{34} \mathrm{O}_{2}$ and $\mathrm{C} 10: 0$ acid values on sheep meat on $\mathrm{EG} 0.8 \% \mathrm{LS}$ $0.2 \%$, EG $0.7 \%$ LS $0.3 \%$ and EG $0.6 \%$ LS $0.4 \%$ treatments. Oleic (C18:1凶9c) acid value of sheep meat on $\mathrm{FG}$, the control treatment was significantly higher $(\mathrm{p}<0.05)$ than those sheep meat on EG $0.6 \%$ LS $0.4 \%$ treatment which in turn were significantly higher $(p<0.05)$ compared with sheep meat on EG $0.7 \%$ LS $0.3 \%$ treatment. Sheep meat on EG $0.7 \%$ LS $0.3 \%$ were significantly higher $(p<0.05)$ in $C 18: 1 \otimes 9 c$ value than those on EG $0.8 \%$ LS $0.2 \%$ treatment which had the lowest ( $p>0.05) \mathrm{C} 18: 1 \otimes 9 \mathrm{c}$ value. The caproleic (C10:1ष9) and linoleic (C18:4(n-6)) acid values of sheep meat on EG 0.6\% LS 0.4\% were significantly higher $(\mathrm{p}<0.05)$ compared with those sheep meat on EG $0.7 \%$ LS $0.3 \%$ which in turn were significantly higher $(p<0.05)$ than those sheep meat on EG. $0.8 \%$ LS $0.2 \%$ treatment. However, the C10:1ه9 and C18:4(n-6) values of sheep meat on EG. $0.8 \%$ LS $0.2 \%$ treatment were significantly higher than those sheep meat on FG, the control treatment which had the lowest $(P>0.05) C 10: 1 \otimes 9$ and $C 18: 4(n-6)$ values. 
Table 7

Fatty Acid Profile of Sheep Meat Fed under Different Treatments

\begin{tabular}{|lllllll|}
\hline Parameters & \multicolumn{2}{l}{ Treatments } & & & & \\
\hline & FG & $\begin{array}{l}\text { EG(0.8\%),LS } \\
(\mathbf{0 . 2 \% )}\end{array}$ & $\begin{array}{l}\text { EG(0.7\%),LS } \\
\mathbf{( 0 . 3 \% )}\end{array}$ & $\begin{array}{l}\text { EG(0.6\%),LS } \\
\mathbf{( 0 . 4 \% )}\end{array}$ & SEM & P value \\
Palmitic & $20.09^{\mathrm{a}}$ & $4.83^{\mathrm{b}}$ & $4.98^{\mathrm{b}}$ & $5.20^{\mathrm{b}}$ & 0.10 & $<0.0001$ \\
Palmitoleic & $1.43^{\mathrm{a}}$ & $0.00^{\mathrm{b}}$ & $0.00^{\mathrm{b}}$ & $0.00^{\mathrm{b}}$ & 0.02 & $<0.0001$ \\
\hline Oleic & $56.99^{\mathrm{a}}$ & $41.20^{\mathrm{d}}$ & $42.30^{\mathrm{c}}$ & $42.96^{\mathrm{b}}$ & 0.11 & $<0.0001$ \\
\hline Myristic & $15.63^{\mathrm{a}}$ & $0.00^{\mathrm{b}}$ & $0.00^{\mathrm{b}}$ & $0.00^{\mathrm{b}}$ & 0.00 & $<0.0001$ \\
Vaccenic & $43.66^{\mathrm{a}}$ & $0.00^{\mathrm{b}}$ & $0.00^{\mathrm{b}}$ & $0.00^{\mathrm{b}}$ & 0.01 & $<0.0001$ \\
\hline Caproic & $3.02^{\mathrm{a}}$ & $0.00^{\mathrm{b}}$ & $0.00^{\mathrm{b}}$ & $0.00^{\mathrm{b}}$ & 0.01 & $<0.0001$ \\
Caproleic & $0.00^{\mathrm{d}}$ & $2.28^{\mathrm{c}}$ & $3.25^{\mathrm{b}}$ & $4.10^{\mathrm{a}}$ & 0.05 & $<0.0001$ \\
\hline Linoleic & $0.00^{\mathrm{d}}$ & $20.41^{\mathrm{c}}$ & $20.98^{\mathrm{b}}$ & $21.65^{\mathrm{a}}$ & 0.01 & $<0.0001$ \\
\hline
\end{tabular}

The means in the rows represented by the same alphabets are not significantly different $(p>0.05)$. FGFree grazing, EG- Elephant grass, LS- Legume straw

\section{Discussions}

\section{Performance}

The high content of crude protein and caloric value of dietary treatment EG $0.6 \%$ LS $0.4 \%$ over other treatments, as well as the digestibility and utilization of this diet by the sheep, could be attributed to the highest final body weight (FBW), total weight gain (TWG), and average weekly weight gain (AWWG) observed in sheep on EG $0.6 \%$ LS $0.4 \%$ treatment as compared to other treatments including the control, despite the sheep's low dry matter consumption on EG $0.6 \%$ LS $0.4 \%$. This observation may indicate that the diet has a higher palatability and nutritional value. This finding is congruent with the conclusions of Bamikole et al. (2003), who found that WAD goats fed Pannicum maximum supplemented with Ficus religiosa had greater weight growth and nutritional digestibility than other treatments up to 75 percent DM given combination. In this study, sheep on dietary treatment EG $0.6 \%$ LS $0.4 \%$ had the lowest feed conversion ratio (FCR) (10.04) when compared to sheep on control free grazing (FG) (15.28). As a result, sheep on the EG $0.6 \%$ LS $0.4 \%$ treatment used their food more efficiently than sheep on the FG, the control diet. This could be due to the right combination of grass and legumes in the diets, which was good for the rumen microorganisms in the sheep, which help with digestion and nutrient utilization. The findings of this investigation are line with the observations of a study on WAD rams fed guinea grass supplemented with processed pigeon pea leaves (Adebisi et al., 2019). 


\section{Nutrient Digestibility}

The sheep on the indoor feeding system (EG 0.6\% LS 0.4\%), which had higher FBW and improved feed conversion efficiency as shown in the lowest FCR, were followed by those on the EG $0.7 \%$ LS $0.3 \%$. This meant that the energy in the form of ether extracts was digested and retained in the gastro intestinal tracts of the sheep than those sheep on FG, the control treatment. It's possible that this is due to increased time spent eating and ruminating. As a result, feed intake is increased, plant materials are digested, and digesta retention time is reduced. The findings of Clauss et al. (2007), who studied the link between feed intake and ingesta passage in cows and sheep, are consistent with those of this study.

\section{Carcass Characteristics}

Indoor raising of WAD sheep with EG $0.8 \%$, LS $0.2 \%$, EG $0.7 \%$, LS $0.3 \%$, and EG $0.6 \%$, LS $0.4 \%$ resulted in higher dry matter intake, resulting in a higher SW value of the experimental animals in those treatments as compared to the control, FG rearing system. This could be due to the sheep on an indoor rearing system's ability to easily absorb and use nutrients without stress or energy expended when compared to those on an FG system. The findings of Ajayi et al. (2012), who fed WAD goats with ensiled mixture of elephant grass and lima beans, African yam bean, and pigeon pea, correlate with the findings of this study. The higher weights observed on the meat cut parts of sheep on the EG $80 \%$, LS $20 \%$, EG $70 \%$, LS $30 \%$, and EG $60 \%$, LS $40 \%$ as compared to the control FG rearing system could be due to the animals in the indoor rearing system better depositing more muscles on their body parts as compared to the control, which must expend more energy walking a long distance before it can graze to maintain its body requirement. The results of this study are consistent with those of Furusho- Garcia et al. (2006), who found that the cut-up sections of sheep given Tifton hay and cassava hay foliage grew at the same rate as the empty body weight. The higher content of abdominal fat (ABF) in sheep on EG $80 \%$, LS $20 \%$ as compared to the control FG may not be due solely to the digestible organic matter present in their diets, which frequently leads to the synthesis of $-\mathrm{OH}$ - butyrate and ruminal propionate, which are known to be precursors for fat synthesis in sheep adipose tissue (Lliotis et al., 2010). But also, because the energy required and spent for movement by the sheep on free grazing will degrade and diminish the rate at which fat is stored by the sheep on free grazing. This result is consistent with Ripoll et al. (2018)'s findings, which show an increase in the percentage of fat in the shoulder of sheep given cassava foliage hay and spineless cactus leaves.

\section{Haematological Parameters}

In this study, the white blood cell counts (WBC), packed cell volume (PCV), and lymphocytes (LYM) for male sheep on the three indoor rearing systems on EG $0.8 \%$, LS $0.2 \%$, EG $0.7 \%$, LS $0.3 \%$, and EG $0.6 \%$, LS $0.4 \%$ and the control, free grazing system (on the same composition of feed) were low compared to the normal range of $7.21 \pm 0.52$ to $7.53 \pm 0.53$ (WBC), $42.88 \pm 0.42$ to $44.0 \pm 0.59$ (PCV) and $82.51 \pm 6.48$ to $100.01 \pm 3.20$ (LYM) for sheep under normal physiological condition (Egbe-Nwiyi et al., 2000). When compared to the control, FG rearing system on the same feed composition, the WBC, PCV, and LYM values of sheep on an indoor rearing system fed EG $0.8 \%$, LS $0.2 \%$ appeared to be greater. This meant that the 
sheep on the EG $0.8 \%$, LS $0.2 \%$ grazing system were clinically healthier than the animals on the free grazing system. This could be due to the physiological stress and immunological response associated with the energy expended in the movement of sheep on free grazing systems in quest of food. The findings of Ajayi et al. (2012), who investigated the haematological indices of WAD goats fed an ensiled mixture of elephant grass with lima bean, African yam bean, and pigeon pea, are consistent with those of this study.

\section{Physico-chemical Properties}

The $\mathrm{pH}$ of the EG $0.6 \%$, LS $0.4 \%$ diet was higher than the control and other treatments, indicating that it was less acidic due to lower lactic acid accumulation in the muscle of the sheep in EG $0.6 \%$, LS $0.4 \%$ diets, which are assumed to be less stressed than sheep on free grazing (control treatment). The findings of this study support Gunenc's (2007) assertion that pre-slaughter stress affects the meat's post-mortem $\mathrm{pH}$. The water retention capacity of sheep reared indoors with EG $0,8 \%$ and LS $0.2 \%$ was higher than that of sheep reared on FG. This could be due to the fact that those animals on EG $0.8 \%$, LS $0.2 \%$ deposited greater muscle. The drip loss of the experimental sheep on the FG rearing system, the control treatment, was larger than that of the sheep on the in-door rearing system with EG $0.8 \%$, LS $0.2 \%$, EG $0.7 \%, \mathrm{LS} 0.3 \%$, and EG $0.6 \%$, LS $0.4 \%$, respectively. This could be due to a slower rate of $\mathrm{pH}$ decrease in sheep meat on FG treatment, indicating faster hydrolysis post mortem (Elisabeth, 2019). The findings of Zhang et al. (2010) in which the water holding capacity and drip loss of sheep fed different diets are compatible with the findings of this study. The redness and lightness of the sheep mutton on FG, the control treatment looked to be superior than sheep mutton on EG $0.8 \%$, LS $0.2 \%$, EG $0.7 \%$, LS $0.3 \%$, and EG $0.6 \%$, LS $0.4 \%$ in an in-door feeding system. This could be due to the amount and type of myoglobin molecules found in the sheep mutton on FG. This research supports the findings of Zembayashi et al. (1999), who found that free range animals have more muscle pigment than stall-fed animals due to higher levels of muscular activity, which causes more myoglobin to be produced in the muscle. Sheep mutton on FG, control treatment had higher shear force values (force peak and yield) than sheep mutton on in-door grazing systems, indicating that sheep mutton on FG is more tender than sheep mutton on in-door grazing systems. This could be due to the increased activity of the sheep's muscles on FG, which raises the degree of mechanical contraction of the myofibrils, one of the elements that influences meat softness. This finding concurs with Reuter et al. (2001), who found that intramuscular activities caused significant changes in tenderness in the biceps femoris, semi-tendinosus, and semi-membranosus muscles of beef.

\section{Sensory Evaluation}

When compared to sheep's meat on FG, the sensory perceptions (taste, texture, aroma, and overall acceptability) of sheep's meat on indoor feeding systems (EG $0.8 \%$, LS $0.2 \%$, EG $0.7 \%$, LS $0.3 \%$, and EG $0.6 \%$, LS $0.4 \%$ ) were better. This could be due to the stress that the sheep on FG are experiencing as a result of the energy that will be lost during feeding. Stress appears to have diminished or degraded those compounds thought to be responsible for the production of taste and scent in the muscle, as well as subsequent muscle fiber development. This finding supports the findings of Byrne et al (2001), who looked into the impact of pre-slaughter stress on warmed-over flavour development in pig meat.

Page 15/19 


\section{Fatty Acid Profiles}

Regardless of the feeding system, the content of saturated fatty acid (palmitic, vaccenic, myristic and caproic acids) and mono-unsaturated fatty acids (oleic and caproleic acids) were more in the sheep's meat on FG system compared to sheep's meat on indoor feeding systems (EG $0.8 \%$, LS $0.2 \%$, EG $0.7 \%$, LS $0.3 \%$ and EG $0.6 \%$, LS $0.4 \%$ ). This could be due to a high concentration of lipids precipitating in the tissue of sheep fed on indoor feeding systems. FG (control) sheep have their lipids easily processed as a result of the movement, which increases muscle activity. This finding reflects those of Roy et al (2013), who looked at the lipid content of muscle in black Bengal goats fed various diets.

\section{Conclusions}

Fattening of WAD sheep on indoor feeding systems especially with EG $0.6 \%$ LS $0.4 \%$ resulted in satisfactory performances, carcass traits (yield, primal cuts and proportion of muscles) and meat quality of the sheep. This is a good incentive for an alternative to free grazing of rearing especially in areas where there are conflicts between the livestock and crop farmers. Consequently, reducing human and material losses on both sides.

\section{Declarations}

\section{Funding}

"This work was supported by [Nigeria Tertiary Educational Trust Fund] (Grant numbers [KWASUETF20171]).

\section{Competing Interests}

"The authors have no relevant financial or non-financial interests to disclose."

\section{Author Contributions:}

"All authors contributed to the study conception and design. Material preparation, data collection and analysis were performed by Hakeem Ishola, Ololade Latifat Abdulrahman, Yusuf Olatunji Ambali, Felicia Motunrayo Olooto, Nofiu Babatunde Nofiu and Ibrahim Folorunsho Ayanda. The first draft of the manuscript was written by Hakeem Ishola] and all authors commented on previous versions of the manuscript. All authors read and approved the final manuscript."

\section{Data Availability}

"The datasets generated during and/or analysed during the current study are not publicly available due to the fact that the manuscript has not been published anywhere but are available from the corresponding author on reasonable request." 


\section{Ethics approval}

All human and animal studies have been approved by the appropriate ethics committee of Kwara State University, Malete, Nigeria and have therefore been performed in accordance with the ethical standards laid down in the 1964 Declaration of Helsinki and its later amendments.

\section{Consent to participate}

Informed consent was obtained from all individual participants included in the study.

\section{Acknowledgement}

The authors would like to thank Prof. D.F. Apata, Prof. T. Olorunsanya for their technical help and Dr. Emeka for his laboratory analyses.

\section{References}

1. Adebisi, I.A., Muraini, T.O., Ajibike, A.B., Okunlola, O.O., Alalade, J.A. \& Oladepo, O. (2019). Growth performance, blood profile and serum metabolites of WAD rams fed guinea grass supplemented with differently processed pigeon pea leaves. Nigerian Journal of Animal Science 21(3): 255-265

2. Adeyemi, K.D., Ebrahimi, M., Samsudin, A.A. Sabow, A.B. \& Sazili, A.Q. (2015). Carcass traits, meat yield and fatty acid composition of adipose tissues and Supraspinatus muscle in goats fed blend of canola oil and palm oil. Journal of Animal Science and Technology. 57:42 DOI 10.1186/s40781-0150076-y

3. Ajayi, F.I., Ogunleke, F., Adesina, A. \& Durotoye, E.S. (2012). Performance, Hematology and Serum Biochemistry of West African Dwarf Goats Fed Ensiled Mixtures of Elephant Grass Pennisetum purpureum with Lima Bean, African Yam Bean and Pigeon Pea. Kasetsart Journals (National Science) 46: 694-702

4. Alexandre, G., Limea, L., Fanchonne, A., Coppry, O., Mandonnet, N. \& Boval, M. (2009). Effect of Forage Feeding on Goat Meat Production: Carcass Characteristics and Composition of Creole Kids Reared Either at Pasture or Indoors in the Humid Tropics. Asian-Australian Journal of Animal Science, 22 (8): 1140-1150

5. AMSA (2012) AMSA Meat Color Measurement Guidelines. American Meat Science Association, Champaign, IL, USA.

6. Bamikole, M.A.; Babayemi, O.J.; Arigbede, O.M. \& Ikhatua, U.J. (2003). Nutritive value of Ficus religiosa in West African dwarf goats. Journals of Animal Feed Science and Technology. 105:71-79.

7. Byrne, D.V., Bredie, W.L.P., Bak, L.S., Bertelsen, G., Martens, H. and Martens, M. (2001). Sensory and chemical analysis of cooked porcine meat patties in relation to warmed-over flavour and preslaughter stress. Meat Science Journal, 59, 229-249

8. Christiansen, F.O., Bakken, M. \& Braastad, B.O. (2001). Behavioural differences between three breed groups of hunting dogs confronted with domestic sheep. Applied Animal Behavioural Science 
Journal. 72:115-129

9. Clauss, M., Streich, W.J., Schwarm, A., Ortmann, S. \& Hummel, J. (2007). The relationship of food intake and ingesta passage predicts feeding ecology in two different megaherbivore groups. OIKOS Advancing Ecology Journals, 116-209. https://doi.org/10.1111/j.0030-299.2007.15461.x

10. Dacie, J.V. \& Lewis, S.M. (2001). Practical Haematology. 9th ed. Churchill Livingstone. London. 663.

11. Egbe-Nwiyi, T.N., Nwaosu, S.C. \& Salami, H.A. (2000). Haematological values of appararently healthy sheep and goats as influenced by age and sex in arid zone of Nigeria. African Journal of Biomedical Research, 3: 109-115

12. Elisabeth, L. H. (2019). Water-holding capacity of fresh meat. Originally published as a National Pork Board/ American Meat Science Association Fact sheet

13. Fleming, P.J.S., Allen, L.R., Lapidge, S.J., Robley, A., Saunders, G.R. \& Thomson, P.C. (2006). A strategic approach to mitigating the impacts of canids: proposed activities of the Invasive Animal Cooperative Centre. Australian Journal of Experimental Agriculture. 46: 753-762

14. Folch, J., Lees, M., \& Sloane-Stanley, G.A. (1957). Simple method for the isolation and purification of total lipids from animal tissues. Journal of Biological Chemistry. 226:497-509.

15. Furusho-Garcia, I.F., Perez, J.R.O., Bonagurid, S. \& Santos, C.L. (2006). Estudo alometrica doscortes de cordeiros santa Ines puros e cruzas. Revista Brasileira De Zootecnia, 35:1416-1422

16. Gunenc A (2007). Evaluation of pork meat quality by using water holding capacity and visspectroscopy (Doctoral dissertation, McGill University).

17. Jain, N.C. (1993). Essential of Veterinary Haematology. Comparative Haematology of Common Domestic Animals. Lea and Febiger. Philadephia, PA, USA. 417

18. Laliotis, G.P., Bizelis, I. \& Rogdakis, E. (2010). Comparative approach of the de novo fatty acid synthesis (lipogenesis) between ruminant and non-ruminant mammalian species: From biochemical level to the main regulatory lipogenic genes. Current Genomics, 11: 168-183

19. Meilgaard, M.C., Carr, B.T. \& Civille, G.V. (2006). Sensory Evaluation Techniques, page 1637, 4th edition. CRC Press, Boca Raton, Florida.

20. Rajion M, McLean J, Cahill RN. (1985). Essential fatty acids in the fetal and newborn lamb. Australian Journal of Biological Science. 38:33-40.

21. Reuter, B. J., Wulf, D. M., Shanks, B. C., Bok, J. M. \& Maddock, R. J. (2001) Proceedings. 54th Annual Recipient of Meat Conference, Indianapolis. p. 187 (AMSA: Chicago)

22. Ripoll, G., Blanco, M., Panea, B. \& Joy, M. (2018). The effect of carcass weight on fatness, muscle and fat colour of male Ojinegra de teruel light lambs. Animal Production Science, 59: 1168-1175.

23. Roy A, Mandal G, Patra A. (2013). Evaluating the performance, carcass traits and conjugated linoleic acid content in muscle and adipose tissues of black Bengal goats fed soybean oil and sunflower oil. Animal Feed Science and Technology; 185:43-52.

24. Sabow AB, Sazili AQ, Zulkifli I, Goh YM, Ab Kadir MZA, Adeyemi KD (2015) Physico-chemical characteristics of longissimus lumborum muscle in goats subjected to halal slaughter and 
anesthesia (halothane) pre-slaughter. Anim. Sci. J 86: 981-991 doi: 10.1111/asj.12385 PMID: 26208249

25. SAS (2014). Statistical Analysis System Package (SAS) Version 9.2 Software. SAS Institute Incorporate, Cary, NC, USA

26. Wood, J.D., Enser, M., Fisher, A.V., Nute, G.R., Sheard, P.R., Richardson, R.I., Hughes, S.I. \& Whittington, F.M. (2008). Fat deposition, fatty acid composition and meat quality: A review. Meat Science Journals. 78:343-358

27. Zembayashi, M., Lunt, D. K. \& Smith, S. B. (1999). Meat Science, 53, 221.

28. Zhang, Y.Y., Zan, L.S., Wang, H.B., Xin, Y.P., Adoligbe, C.M. \& Ujan, J.A. (2010). Effect of sex on meat quality characteristics of Qinchuan cattle. African Journal of Biotechnology. 9(28):4504-4509 